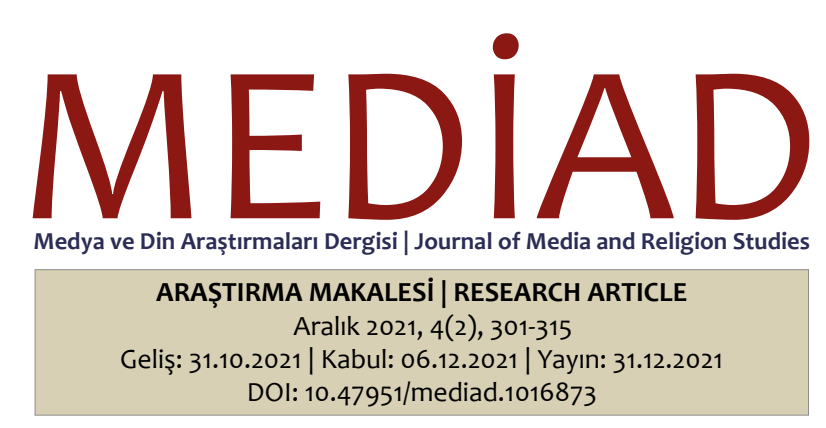

\title{
Sosyal Medyada Paylaşılan Hadislerin Dinî Yaşantıya Etkisi: Balıkesir Üniversitesi Öğrencileri Örneği'
}

\begin{abstract}
Recep Emin GÜL*
Öz

Bu çalışmada sosyal medyada paylaşılan hadislerin dinî yaşantıya olan etkisi incelenmiştir. Araştırmada nicel yöntem benimsenmiş, araştırma verileri hazırlanan anket yoluyla toplanmıştır. Araştırmanın evrenini Balıkesir Üniversitesi öğrencileri, örneklemini ise basit rastlantısal yöntemle seçilmiş 317 öğrenci oluşturmaktadır. Araştırmanın amacı günümüzde bilgi paylaşım araçlarından biri haline gelen sosyal medyada paylaşılan hadislerin örneklem grubunun dinî yaşantısına ne oranda etki ettiğini tespit etmektir. Bu amaca uygun olarak katılımcılara sekiz ana başlıkta bazı önermeler sunulmuştur. Araştırmada elde edilen verilere göre katılımcıların çok büyük bir kısmı sosyal medyaya ve burada paylaşılan hadislere güvenmemektedir. Bununla birlikte katılımcıların sekiz ana başlıktan üçünü \%50'nin altında bir oranla; beş başlığı ise \%50'nin üzerinde dinî yaşantılarına aktardığı tespit edilmiștir. Araștırmada ulașılan sonuçlardan hareketle sosyal medya kullanıcılarının gizil (örtük) öğrenme yöntemiyle sosyal medyada paylaşılan hadislerdeki dinî bilgileri öğrendiklerini ve dinî yaşantılarına aktardıklarını söylemek mümkündür.
\end{abstract}

Anahtar Kelimeler: Hadis, Sosyal Medya, Dinî Yaşantı, Üniversite Öğrencileri, Balıkesir

\section{The Effect of Hadith Shared on Social Media on Religious Life: The Sample of Balikesir University Students}

\begin{abstract}
In this study, the effect of hadiths shared on social media on religious life was examined. A quantitative method was adopted in the research, and research data were collected through a questionnaire. The population of the research consists of Balıkesir University students, and the sample consists of 317 students selected by a simple random method. Following this aim, some suggestions were presented to the participants under eight main headings. According to the data obtained in the research, the majority of the participants do not trust social media and the hadiths shared here. However, it was determined that the participants transferred three of the eight main headings to their religious life with a rate below $50 \%$, and the five headings over $50 \%$. Based on the results of the research, it is possible to say that social media users learn the religious information in the hadiths shared on social media with the latent (implicit) learning method and transfer them to their religious lives.
\end{abstract}

Keywords: Hadith, Social Media, Religious Life, University Students, Balıkesir

ATIF: Gül, R. E. (2021). Sosyal medyada paylaşılan hadislerin dinî yaşantıya etkisi: Balıkesir Üniversitesi ögrrencileri örneği. Medya ve Din Araştırmaları Dergisi (MEDiAD), 4(2), s. 301-315. 


\section{Giriş}

İnsanlık tarih boyunca farklı alanlarda bilgi üretmiş ve çeşitli yollarla bu bilgileri sonraki nesillere aktarmıştır. Yirmi birinci yüzyılın önemli bilgiaktarma araçlarından birisinin ise sosyal medya olduğunu söylemek yanlış olmayacaktır. İnsanlar hayatın hemen her alanıyla ilgili bilgileri bu mecradan paylaşabilmektedir. Paylaşılan bu bilgiler arasında dinî alanı ilgilendirenlerin yoğunluğu ise ayrıca dikkat çekmektedir. Sosyal medya kullanıcıları bu mecrada çoğunluğunu ayet-hadis ve din büyüklerinin sözlerinin oluşturduğu dinî bilgiler paylaşmaktadır. Bu durum aslında kullanıııların, dinî bilgilerin paylaşımı için sosyal medyayı uygun bir araç olarak gördüklerini ve bu mecrada dinî bilgi paylaşmanın faydalı olduğunu düşündüklerini göstermektedir (Korukcu, Cengil, \& Ardahanlı, 2015, s. 530). Hatta sosyal medya, dinî bilgilerin paylaşıldığı bir mecra olarak, gençler tarafından dinî bilgiye ulaşmada ilk başvuru kaynaklarından kabul edilmektedir (Ayaz, 2015, s. 118; Demir, 2019, s. 73; Yavuz, 2020, s. 126). Nitekim bazı araştırmalarda katılımcıların büyük çoğunluğunun interneti ve sosyal medyayı bilgi almak amacıyla kullandığı tespit edilmiştir (Altuntaş \& Kul, 2015, s. 422; Çiftçi, 2018, s. 429).

Konuyla ilgili Ayaz'ın yaptığı araştırmada ise özellikle ergenlik dönemindeki gençlerin sosyal medyadaki dinî toplulukların paylaşımlarını takip ettikleri, sosyal medyayı kendileri için sanal bir tekke, zaviye veya cemaat evi gibi gördükleri tespit edilmiştir (2015, ss. 115-116). Gençlerin bazı dinî bilgilerini sosyal medyadan öğrendiklerini belirtmeleri de bu durumun bir göstergesidir (Demir, 2019, s. 73). Gençler, sosyal medyanın tebliğ ve irşat hizmetleri için önemli bir araç olduğunu, sosyal medyada karşılaştıkları bilgilerin dini öğrenme merakını artırdığını, bu mecradaki dinî içerikli paylaşımları daha dikkatli okuduklarını, sosyal medya sayesinde hadisler hakkında daha fazla bilgi sahibi olduklarını ifade etmektedir (Bildik, 2019, ss. 97-101; Dereli, 2020, ss. 239-242). Bununla birlikte gençlerin önemli bir kısmı sosyal medyada kaynağıyla birlikte paylaşılan dinî bilgilere güvendiklerini ve bu bilgilerin dinî yaşantılarına etki ettiğini belirtmektedir (Bildik, 2019, ss. 104-107). İște bu noktada sosyal medyada paylaşılan dinî bilgiler için verilen kaynakların ne derece güvenilir olduğu önem arz etmektedir. Zira özellikle sosyal medyada paylaşılan hadislerin çoğu zaman yanlış kaynak kullanılarak paylaşııdığını söylemek mümkündür (Gül, 2016, ss. 172, 175-177). Farklı alanlarda yapılan çalışmalarda da aynı soruna dikkat çekildiği görülmektedir (Korukcu vd., 2015, s. 514; Demir, 2019, s. 149). ${ }^{2}$ Çok yaygın ve genel bir tavır olmasa da sosyal medyanın dinî bilgi edinme kaynağı olarak kullanılıyor olması içerisinde yer alan dinî bilgilerin de güvenilir olmasını gerekli kılmaktadır. Bu noktada özellikle dinî, dünyevî, kişisel vb. bazı çıkarlar sebebiyle istismara açık veya bağlamından koparılan ve tek başına anlaşılması güç hadis paylaşımlarına ayrıca dikkat çekmek gerekmektedir.

Sosyal medyanın dinî bilgi edinme aracı olarak kullanılması gizil (örtük) öğrenme metodunu akla getirmektedir. Bu öğrenme türünde bireyler algıda seçicilik veya dikkat dağılması gibi nedenlerle bazı bilgileri farkına varmadan öğrenirler. Birey ancak ihtiyaç duyduğunda bu bilginin farkına varır. Eğitimciler "bilişsel harita", "bilişsel senaryo" ve "yan ürün" olmak üzere gizil öğrenmenin üç türünden bahsederler (Bacanl, 2002, s. 192, 2015, s. 245; Karip, 2014, s. 139). Sosyal medyada karşılaşılan dinî bilgilerin farkına varılmadan öğrenilmesini de "yan ürün" kategorisine dâhil etmek mümkündür. Zira kullanıcılar sosyal medyayı o bilgileri öğrenmek için kullanmazlar ancak karşılaştıklarında farkına varmadan öğrenirler.

Yukarıdaki bilgilerden anlaşıldığı kadarıyla sosyal medyanın dinî bilgi edinme kaynağı olarak kullanılması hakkında farklı sonuçlara ulaşıımıștır. Ancak sosyal medyada paylaşılan bu dinî bilgilerin kullanıııların dinîyaşantısına etkisi konusunda yapılmış herhangi bir çalışma ise tespit edilememiştir. Bu sebeple çalışmada sosyal medyada paylaşılan dinî bilgiler içerisinde önemli bir yere sahip olan hadislerin üniversite öğrencilerinin dinî yaşantılarına etkisi tespit edilmeye çalışılmışıır. Bunun için öncelikle sosyal medyanın dünya ve Türkiye'deki kullanım verilerine değinilecek, ardından çalışmanın yöntemi açıklanacak ve son olarak da elde edilen bulgular aktarılarak yorumlanacaktır.

\section{Sosyal Medya Kullanım Verileri}

Dünya genelindeki 4.2 milyar sosyal medya kullanıcısı günde yaklaşık 2 saat 25 dakikasını sosyal medyada geçirmektedir. Çalışmanın kapsamına alınan Facebook dünya genelinde 2.2 milyar, Türkiye'de 38 milyon; Instagram dünya genelinde 1.2 milyar, Türkiye'de 46 milyon; Twitter dünya genelinde 363.1 milyon, Türkiye'de 13.6 milyon; Whatsapp ise dünyada 2 milyar kişi tarafından kullanılmaktadır. Türkiye Facebook kullanımında dünyada on ikinci, Instagram kullanımında altıncı, Twitter kullanımında ise yedinci sıradadır (Wearesocial, 2021).

Türkiye'nin 2020 yılı itibariyle nüfusu 84.69 milyondur. Türkiye'deki aktif sosyal medya kullanıcısı ise 60 milyondur (nüfusun \%70.8'i). Türkiye'de aktif sosyal medya kullanııısı bir önceki yıla göre 6 milyon artmıştır. Türkiye günde 2 saat 57 dakikasını sosyal medyada geçirmektedir. Türkiye'de internet kullanıcılarının en fazla 
kullandıkları platformlar sırasıyla Youtube, Instagram, Whatsapp, Facebook ve Twitter'dır. Türk insanı aylık ortalama 19.7 saat Instagram'da; 15 saat Whatsapp'ta, 13.1 saat Facebook'ta ve 7.8 saat Twitter'da vakit geçirmektedir (Datareportal, 2021).

Türk gençliğinin sosyal medya kullanımına yönelik yapılan araştırmalar da yukarıdaki bilgileri doğrular niteliktedir. Nitekim Eldem ile Elibol'un yaptığı araştırmada üniversite öğrencilerinin zamanlarının büyük bir kısmını Instagram'da harcadıkları belirtilirken (2020, s. 163); Altuntaş ile Kul'un çalışmasında ise üniversite öğrencilerinin \%75,2'sinin sosyal medyayı sürekli kullandığı ve en fazla kullanılan sosyal medya uygulamasının \%82,6 ile Facebook olduğu sonucuna varılmıştır (2015, s. 421). Yine diğer bir araştırmada katılımcıların büyük çoğunluğunun sosyal medyada 3-6 saat arası vakit geçirdiği tespit edilmiştir (Özgür Güler, Veysikarani, \& Keskin, 2019, s. 4). İnce ile Koçak'ın araştırmasında ise üniversite öğrencilerinden oluşan katılımcıların en çok Facebook, Twitter ve Instagram kullandığı ve orta düzeyde sosyal medya bağımlısı olduğu sonucuna varılmıştır (2017, ss. 742-746). Üniversite öğrencileri üzerine yapılan bir başka araştırmada ise katılımcıların \%67,5'inin uykudan kalktıklarındaki ilk on beş dakika içinde sosyal medya hesaplarını kontrol ettiği tespit edilmiştir (Ö. Avcı \& Sürücü, 2018, s. 505). Karaboğa tarafından yapılan araştırmada üniversite öğrencilerinin günlük ortalama sosyal medya kullanım süresi 4 saat 15 dakika olarak tespit edilirken öğrencilerin en çok Instagram, Whatsapp, Twitter ve Facebook kullandığı belirtilmiştir (2018, ss. 922-925). 704 üniversite öğrencisi üzerinde yapılan diğer bir araştırmada da katılımcıların büyük çoğunluğunun günlük 3-6 saat arası sosyal medyada zaman harcadığı ve Instagram, Whatsapp, Twitter ve Facebook'un en çok kullanılan uygulamalar olduğu sonucuna ulaşılmıştır (Caz \& Bardakçı, 2019, s. 1107).

Yukarıdaki verilerden anlaşıldığı kadarıyla Türk insanı ve özellikle gençler gününün önemli bir kısmını sosyal medyada geçirmekte, farklı amaçlarla birlikte bilgi paylaşımı ve kaynağı olarak da sosyal medyanın imkânlarını kullanmaktadır. Bu nedenle sosyal medyanın Türkiye'deki etkisini görmezden gelmek mümkün değildir. Her türlü bilginin paylaşımına imkân tanıması sosyal medyayı aynı zamanda dinî bilgilerin ve özellikle hadislerin de paylaşım alanı durumuna getirmektedir. Her gün çok sayıda hadis veya hadis olduğu iddia edilen metin sosyal medyada paylaşılmaktadır. Bu noktada sosyal medyada paylaşılan hadislerin toplumun dinî yaşantısına etki edip etmediği veya ne derece etki ettiği araştırılması gereken önemli bir konu olarak değerlendirilmiştir.

\section{Yöntem}

Araştırmanın amacı sosyal medyada paylaşılan hadislerin insanların dinî yaşantılarına etki derecesini belirlemektir. Bu çalışma, günümüzde artık önemli bir iletişim aracı olan ve insanların her türlü bilgiye kolayca ulaşabildiği sosyal medyanın insanların dinî yaşantılarına etkisinin boyutunu tespit edebilmek adına önemlidir.

Nicel desende tasarlanan araştırmada hazırlanan anket yoluyla toplanan veriler analize tabi tutulmuştur. Örneklem grubuna uygulanan ankette 4 demografik soru, katılımcıların dinî yaşantılarıyla ilgili bir dizi önerme içeren 13 adet beşli likert madde (hiçbir zaman, nadiren, bazen, çoğu zaman, her zaman) ve katılımcıların sosyal medya ve burada paylaşılan bilgilere güven düzeyini ölçmeye yönelik bir dizi önerme içeren 5 adet beşli likert madde (kesinlikle katılıyorum, katılıyorum, kısmen katılıyorum/kararsızım, katılmıyorum, kesinlikle katılmıyorum) olmak üzere toplam 22 maddeye yer verilmiştir. Anketin katılımcılara uygulanabilmesi için Balıkesir Üniversitesi'nden gerekli izinler ve Etik Kurul Onayı alınmıştır. Covid-19 Pandemi koşulları göz önünde bulundurularak anket formu öğrencilere matbu olarak değil online ulaştırılmıştır. Çalışmada genel olarak sosyal medyada paylaşılan hadislerin kullanıcıların dinî yaşantısına etki oranını tespit etmek amaçlandığından ve elde edilen verilerin frekans dağılımları çalışmanın amacına uygun düştüğünden bu çalışmada frekans dağılımları ile yetinilmiştir.

Anketin oluşturulma sürecinde öğrencilerle yapılan görüşmeler ve uzman görüşleri doğrultusunda çalışmada kullanılan kategorilerden "Her Zaman”, "Çoğu Zaman” ve "Bazen” kategorilerinin birleștirilerek olumlu yönde; “Nadiren” ve "Hiçbir Zaman” kategorilerinin de birleştirilerek olumsuz yönde değerlendirilmesine karar verilmiştir. Yine "Kesinlikle Katılmıyorum” ve "Katılmıyorum” kategorileri birleștirilerek olumsuz; “Kesinlikle Katılıyorum” ve “Katılıyorum” kategorileri birleştirilerek olumlu; “Kararsızım/Kısmen Katılıyorum” kategorisi ise nötr olarak değerlendirilmiştir.

Araştırmanın amacı doğrultusunda çalışmanın hipotezleri ise şu şekildedir:

1. Sosyal medya, Balıkesir Üniversitesi öğrencilerinin günlük yaşantısında önemli bir yere sahiptir.

2. Sosyal medyada paylaşılan hadisler Balıkesir Üniversitesi öğrencilerinin ilgi alanına girmektedir.

3. Sosyal medyada paylaşılan hadislerde yer alan dinî bilgiler Balıkesir Üniversitesi öğrencilerinin dinî yaşantısına belli oranda etki etmektedir. 


\subsection{Etik Kurul Raporu}

Balıkesir Üniversitesi Sosyal ve Beşeri Bilimler Etki Komisyonu’nun 17/06/2021 tarihli kararı çerçevesinde çalışma etik açıdan bir sakınca içermemektedir. Etik değerlendirme kararı belge tarihi: 23/06/2021. Etik değerlendirme belgesi sayı numarası: E-89312250-900-41938

\subsection{Araştırmanın Evreni ve Örneklemi}

Araştırmanın evrenini Balıkesir ilinde eğitim gören üniversite öğrencileri oluşturmaktadır. Üniversite öğrencilerinin sosyal medyayı en sık kullanan yaş grupları içerisinde yer almaları araştırmanın hedef kitlesi olarak seçilmelerinde belirleyici olmuştur. ${ }^{3}$ Araştırmanın örneklemini ise Balıkesir Üniversitesi'nde eğitim gören ve rastlantısal örnekleme yöntemiyle seçilmiş olan, 3. ve 4. sınıfta öğrenim gören $220(\% 69,6)$ kız, $97(\% 30,4)$ erkek olmak üzere toplam 317 öğrenci oluşturmaktadır. Bu öğrencilerden 125’i $(\% 39,4)$ ilahiyat Fakültesi öğrencisi, 192'si $(\% 60,6)$ ise diğer fakültelerin öğrencisidir. Ayrıca sosyal medya platformlarının çeşitliliği ve fazlalığı göz önünde bulundurularak çalışma Türkiye'de en çok kullanılan sosyal medya platformları Instagram, Facebook, Whatsapp ve Twitter ile sınırlı tutulmuştur.

Araştırma verileri 2020-2021 eğitim-öğretim yılının Bahar döneminde elde edilmiştir. Çalışmanın evrenini oluşturan Balıkesir Üniversitesinde 2020-2021 eğitim-öğretim yılında 13.242 kız, 16.291 erkek olmak üzere toplam 29.533 öğrenci kayıtlıdır. İlahiyat Fakültesinde ise aynı dönemde 373 kız, 283 erkek olmak üzere toplam 656 öğrenci kayıtlıdır. Çalışmanın örneklemini oluşturan 317 öğrenci toplam evrenin \% 1,07'sini oluşturmakta ve \% (+ -) 5 hata payıyla temsil kabiliyetinin bulunduğu düşünülmektedir (Baş, 2006, s. 47). ilahiyat Fakültesi öğrencilerinin almış oldukları hadis eğitimi göz önünde bulundurularak araştırmada elde edilen veriler, illahiyat Fakültesi öğrencileri ve diğer fakülte öğrencileri arasında bir karşılaştırmaya da tabi tutulmuştur.

\section{Bulgular}

\subsection{Katılımcıların Sosyal Medya Kullanımına Dair Bulgular}

Katılımcıların sosyal medyada karşılaştıkları hadislerde yer alan dinî bilgileri hayatlarına aktarma oranlarını tespit edebilmek için öncelikle sosyal medyayı ne sıklıkla kullandıklarını belirlemek gerekmektedir. Bu amaçla katılımcılara "Sosyal medyayı kullanırım” önermesi yöneltilmiştir.

Tablo 1. Sosyal Medya Kullanırım.

\begin{tabular}{lllll}
\hline Kategoriler & Kadın & Erkek & Toplam & Yüzde \\
\hline Her Zaman & 78 & 30 & 108 & 34,1 \\
\hline Çoğu Zaman & 104 & 47 & 151 & 47,6 \\
\hline Bazen & 27 & 12 & 39 & 12,3 \\
\hline Nadiren & 9 & 8 & 17 & 5,4 \\
\hline Hiçbir zaman & 2 & 0 & 2 & 0,6 \\
\hline Toplam & $\mathbf{2 2 0}$ & 97 & 317 & $\mathbf{1 0 0}$ \\
\hline
\end{tabular}

Tablodan anlaşılacağı üzere katılımcıların büyük bir kısmının (\%94; 298 kişi) sosyal medyayı sıklıkla kullandığı; az bir kısmının ise (\% 6; 19 kişi) sosyal medyayı neredeyse hiç kullanmadığı tespit edilmiştir. Kadın katılımcıların \%95’i (209 kişi) sosyal medyayı sık kullanırken; erkek katılımcıların ise \%92'si (89 kişi) sosyal medyayı sıklıkla kullanmaktadır. Bu rakamlardan anlaşıldığı üzere katılımcıların çok büyük bir kısmı aktif sosyal medya kullanıcısıdır. Böylece çalışmanın ilk hipotezinin bu verilerle doğrulandığını söylemek mümkündür. Türkiye'deki sosyal medya kullanım verilerine dair yukarıda verilen bilgilerle çalışmada elde edilen verilerin uyumlu olduğu ve gençlerin sosyal medyayı aktif bir şekilde kullandıkları anlaşılmaktadır.

Katılımcıların sosyal medyada paylaşım yapma oranları ise yukarıdaki verilere oranla daha düşüktür. Nitekim katılımcıların \%63’ü (200 kişi) sosyal medyada paylaşım yaptığını belirtirken geri kalan \%37’lik (117 kişi) kısım ise paylaşım yapmadığını ifade etmiştir. Katılımcıların sosyal medyada karşılaştıkları hadisleri diğer kulla- 
nıcılarla paylaşma oranı ise daha düşüktür. Katılımcıların sadece \%33,8’i (107 kişi) sosyal medyada karşılaştıkları hadisleri diğer kullanıcılarla paylaştıklarını ifade ederken \%66,2'si (210 kişi) ise paylaşmadıklarını belirtmiştir. Katılımcıların sosyal medyaya olan güvenlerinin de son derece düşük olduğu tespit edilmiştir. Katılımcıların yalnızca \%2,2'si (7 kişi) sosyal medyaya güvenirken \%55,5’i (176 kişi) güvenmemekte; \%42,3'ü ise (114 kişi) ise kararsız olduğunu bildirmektedir.

\subsection{Sosyal Medyada Paylașılan Hadislerin Katılımcıların Dinî Yașantısına Etkisine Dair Bulgular}

Hadislerin sıhhatini belirlemede öncelikli olarak yapılması gereken işlemlerden birisi şüphesiz ki kaynak tespiti olmalıdır. Bu durum sosyal medyada paylaşılan hadisler için daha da önem kazanmaktadır. Zira sosyal medyada paylaşılan hadislerde çoğu zaman kaynak verilmediği, verildiği zamanlarda ise yanlış kaynaklara atıf yapılabildiği görülmektedir (Gül, 2016, ss. 170-173). Bu sebeple katılımcıların kaynak bilinçlerini ölçmeye yönelik olarak sosyal medyada paylaşılan hadislerin kaynaklarını araştırma oranlarını tespite yönelik bir önerme yöneltilmiştir.

\begin{tabular}{lcccc}
\hline \multicolumn{5}{l}{ Tablo 2. Sosyal medyada paylaşılan hadislerin kaynağını araştırırım. } \\
\hline Kategoriler & Kadın & Erkek & Toplam & Yüzde \\
\hline Her Zaman & 13 & 8 & 21 & 6,6 \\
\hline Çoğu Zaman & 37 & 12 & 49 & 15,5 \\
\hline Bazen & 57 & 28 & 85 & 26,8 \\
\hline Nadiren & 58 & 31 & 89 & 28,1 \\
\hline Hiçbir zaman & 55 & 18 & 73 & 23 \\
\hline Toplam & 220 & 97 & 317 & 100
\end{tabular}

Katılımcıların \%51,1'inin (162 kişi) kaynak araştırması yapmadığı, \%48,9'unun (155 kişi) ise sosyal medyada karşılaştığı hadislerin kaynaklarını araştırdığı tespit edilmiştir. İlahiyat Fakültesi öğrencilerinin \%59'u (74 kişi); diğer fakülte öğrencilerinin ise \%42'si (81 kişi) sosyal medyada paylaşılan hadislerin kaynaklarını araştırdığını ifade etmektedir. Anlaşıldığı kadarıyla illahiyat Fakültesi öğrencileri aldıkları hadis eğitiminin bir sonucu olarak diğer fakülte öğrencilerine oranla daha fazla kaynak bilincine sahiptirler. Nitekim Kesgin tarafından yapılan bir araştırmada örneklem grubunu oluşturan illahiyat Fakültesi öğrencilerinin büyük çoğunluğu bir hadisin kaynağını araştırmayı ve hadisi kaynağından bulmayı bildiğini ifade etmiştir (2016, s. 31). Bununla birlikte tespit edilen bu oran katılımcıların kaynak bilinci bakımından aslında olumlu bir noktada olduklarını göstermesi açısından önemlidir. Bu durumda katılımcıların \%46,1'inin (146 kişi) hadis eğitimi almış olmasının etkisinin olduğu da söylenebilir. Araştırmada katılımcıların sosyal medyada karşılaştıkları hadislerin içeriklerine dikkat etme oranı da tespit edilmiştir. Buna göre katılımcıların \%81,4'ü (258 kişi) hadislerin içeriğine dikkat ederken \%18,6'sı (59 kişi) ise dikkat etmemektedir. Katılımcıların gerek sosyal medyada paylaşılan hadisleri diğer kullanıcılarla paylaşma oranları gerekse büyük bir çoğunluğunun hadislerin içeriğine dikkat etmesi çalışmanın ikinci hipotezini doğrular niteliktedir.

Katılımcıların yarısından fazlasının sosyal medyada paylaşılan hadislerin kaynağını araştırma ihtiyacı hissetmesinin, sosyal medyada paylaşılan hadislere güvenmemeleriyle bağlantılı olduğu söylenebilir.

Tablo 3. Sosyal medyada paylaşılan hadislere güvenirim.

\begin{tabular}{lllll}
\hline Kategoriler & Kadın & Erkek & Toplam & Yüzde \\
\hline Kesinlikle Katılıyorum & 0 & 0 & 0 & 0 \\
\hline Katılıyorum & 6 & 15 & 21 & 6,6
\end{tabular}




\begin{tabular}{lcccc}
\hline $\begin{array}{l}\text { Kısmen Katılıyorum / Kararsı- } \\
\text { zım }\end{array}$ & 128 & 53 & 181 & 57,1 \\
\hline Katılmıyorum & 56 & 17 & 73 & 23 \\
\hline Kesinlikle Katılmıyorum & 30 & 12 & 42 & 13,2 \\
\hline Toplam & $\mathbf{2 2 0}$ & $\mathbf{9 7}$ & 317 & $\mathbf{1 0 0}$ \\
\hline
\end{tabular}

Yukarıdaki tabloda da görüleceği üzere katılımcıların \%36,2'si (115 kişi) sosyal medyada paylaşılan hadislere güvenmediğini belirtmektedir. Sosyal medyada paylaşılan hadislere güvenenlerin oranı \%6,6 (21) iken katılımcıların büyük kısmının (\%57,1, 181 kişi) ise kararsız olduğu anlaşılmaktadır. illahiyat Fakültesi öğrencilerinin \%49'u (62 kişi); diğer fakülte öğrencilerinin ise \%28'i (53 kişi) sosyal medyada paylaşılan hadislere güvenmemektedir. Görüldüğü üzere illahiyat Fakültesi öğrencilerinin sosyal medyada paylaşılan hadislere güven oranı diğer fakülte öğrencilerine göre daha düşüktür. Kesgin tarafından ilahiyat Fakültesi öğrencileri üzerine yapılan araştırmada da katılımcıların büyük çoğunluğunun sosyal medyada paylaşılan hadislere güvenmediği tespit edilmiştir (2016, s. 37).

Sosyal medyada paylaşılan hadislerin katılımcıların dinî yaşantısına etki oranını ölçmek üzere katılımcılara zikir, dua, nafile ibadetler, ahlâkî kurallar, kılık-kıyafet önerileri vb. içerikli hadisleri hayatlarına aktarma oranlarına dair önermeler yöneltilmiştir. Toplam sekiz başlıkta yöneltilen bu önermelerden üçünde yer alan bilgileri katılımcılar \%50'nin altında bir oranla dinî yaşantılarına aktarırken beş önermede ise bu oran \%50'nin üstüne çıkmıştır.

Hz. Peygamber'in (sas) günlük yaşamda yapılmasına yönelik ümmetine birçok zikir öğrettiği ve tavsiye ettiği bilinmektedir. Bu durum göz önünde bulundurularak katılımcılara "Sosyal medyada paylaşılan bir hadisten öğrendiğim zikirleri yapmaya özen gösteririm." şeklinde bir önerme yöneltilmiştir.

\begin{tabular}{lllll}
\hline \multicolumn{5}{c}{ Tablo 4. Sosyal medyada paylaşılan bir hadisten öğrendiğim zikirleri } \\
yapmaya özen gösteririm.
\end{tabular}

Katııımcıların \%45,8'i (145 kişi) sosyal medyada karşılaştığı hadisten öğrendiği zikirleri günlük yaşantısında yapmaya özen gösterdiğini belirtmiştir. Bu oran ilahiyat Fakültesi öğrencilerinde \%48 (60 kişi), diğer fakülte öğrencilerinde ise \%44'tür ( 85 kişi). illahiyat Fakültesi öğrencilerinin diğer fakülte öğrencilerine oranla sosyal medyada karşılaştığı hadislerde yer alan zikirleri dinî yaşantısına aktarma oranı az bir farkla da olsa daha yüksektir. Katılımcıların \%54,2'sinin (172 kişi) ise sosyal medyada paylaşılan hadislerden öğrendiği zikirleri dinî yaşantısına aktarmadığı anlaşılmaktadır.

Katılımcıların sosyal medyada karşılaştıkları hadislerde hakkında bilgi verilen nafile namazları ${ }^{4}$ dinî hayatlarına aktarma oranı da tespit edilmeye çalışılmışıır. 


\begin{tabular}{lcccc}
\multicolumn{5}{c}{ Tablo 5. Sosyal medyada paylaşılan bir hadisten öğrendiğim nafile na- } \\
mazları kılmaya özen gösteririm. \\
Kategoriler & Kadın & Erkek & Toplam & Yüzde \\
\hline Her Zaman & 1 & 3 & 4 & 1,3 \\
\hline Çoğu Zaman & 12 & 4 & 16 & 5 \\
\hline Bazen & 45 & 23 & 68 & 21,5 \\
\hline Nadiren & 55 & 27 & 82 & 25,9 \\
\hline Hiçbir zaman & 107 & 40 & 147 & 46,4 \\
\hline Toplam & 220 & 97 & 317 & 100 \\
\hline
\end{tabular}

Yukarıdaki verilerden anlaşıldığı üzere katılımcıların \% 27,8'inin (88 kişi) sosyal medyada paylaşılan hadislerden öğrendikleri nafile namazları dinî yaşantılarına aktardığı, \%72,2'sinin (229 kişi) ise aktarmadığı tespit edilmiştir. îlahiyat Fakültesi öğrencilerinin \%69,5’i (87 kişi), diğer fakülte öğrencilerinin ise \%74'ü (142 kişi) sosyal medyada paylaşılan hadislerden öğrendiği hadislerde yer alan nafile namazları dinî yaşantısına aktarmamaktadır. Görüldüğü üzere illahiyat Fakültesi öğrencilerinin diğer fakülte öğrencilerine oranla sosyal medyada paylaşılan hadislerden öğrendikleri nafile namazları dinî yaşantılarına aktarma oranı \%4,5 daha yüksektir.

Katılımcıların dinî yaşantılarına aktarma oranlarının \%50’nin altında kaldığı diğer bir madde ise sosyal medyada paylaşılan hadislerde yer alan nafile oruç konusudur.

Tablo 6. Sosyal medyada paylaşılan bir hadisten öğrendiğim nafile oruçları tutmaya özen gösteririm.

\begin{tabular}{lcccc}
\hline Kategoriler & Kadın & Erkek & Toplam & Yüzde \\
\hline Her Zaman & 6 & 3 & 9 & 2,8 \\
\hline Çoğu Zaman & 15 & 4 & 19 & 6 \\
\hline Bazen & 46 & 21 & 67 & 21,1 \\
\hline Nadiren & 52 & 31 & 83 & 26,2 \\
\hline Hiçbir zaman & 101 & 38 & 139 & 43,8 \\
\hline Toplam & $\mathbf{2 2 0}$ & $\mathbf{9 7}$ & $\mathbf{3 1 7}$ & $\mathbf{1 0 0}$ \\
\hline
\end{tabular}

Katılımcıların \%29,9'u (95 kişi) bu oruçları tutmaya özen gösterdiğini ifade ederken \%70,1’i (222 kişi) ise tutmadığını belirtmiştir. İlahiyat Fakültesi öğrencilerinden \%29'u (36 kişi) sosyal medyada paylaşılan hadislerde yer alan nafile oruçları tuttuğunu belirtirken bu oran diğer fakülte öğrencilerinde \%30,6 (59 kişi) ile az da olsa yükselmiştir.

"Sen elbette üstün bir ahlâka sahipsin." (Kalem 68/4) ayetiyle Allah (cc) tarafından bizlere en güzel örnek olarak gösterilen Hz. Peygamber (sas) ümmetinin de ahlâklı birer birey olması için çok sayıda uyarı ve tavsiyede bulunmuştur. Hz. Peygamber'in bu uyarı ve tavsiyelerini içeren çok sayıda hadis yahut hadis olduğu söylenen metin sosyal medyada paylaşılmaktadır. Bu nedenle katılımcıların sosyal medyada paylaşılan hadislerde yer alan ahlâkî kurallara uyma oranları ölçülmüştür. 
Tablo 7. Sosyal medyada paylaşılan bir hadisten öğrendiğim ahlâkî kurallara (yalan söylememek, iftira atmamak, yardımlaşmak vb.) uymaya özen gösteririm.

\begin{tabular}{lllll}
\hline Kategoriler & Kadın & Erkek & Toplam & Yüzde \\
\hline Her Zaman & 47 & 25 & 72 & 22,7 \\
\hline Çoğu Zaman & 104 & 39 & 143 & 45,1 \\
\hline Bazen & 35 & 13 & 48 & 15,1 \\
\hline Nadiren & 20 & 12 & 32 & 10,1 \\
\hline Hiçbir zaman & 14 & 8 & 22 & 6,9 \\
\hline Toplam & $\mathbf{2 2 0}$ & $\mathbf{9 7}$ & $\mathbf{3 1 7}$ & $\mathbf{1 0 0}$ \\
\hline
\end{tabular}

Katılımcıların en yüksek oranda dinî yaşantılarına aktardıkları alanın hadislerde yer alan ahlâkî kurallara yönelik bu uyarı ve tavsiyeler olduğu görülmektedir. Nitekim katılımcıların \%82,9'u (237 kişi) sosyal medyada paylaşılan hadislerde yer alan ahlâkî kurallara yönelik tavsiyeleri dinî yaşantısına aktarmaya özen gösterdiğini ifade ederken sadece \%17,1’i (80 kişi) bu tavsiyeleri dikkate almadığını belirtmiştir. Görüldüğü gibi katılımcıların çok büyük bir kısmı sosyal medyada paylaşılan hadislerde yer alan yalan söylememek, iftira atmamak, yardımlaşmak vs. gibi ahlâkî kurallara yönelik bilgileri dinî yaşantılarına aktarmaktadır. İlahiyat Fakültesi öğrencilerinde bu oran \%87 (108 kişi) iken diğer fakülte öğrencilerinde ise \%80,5 (155 kişi) olmuştur. Sosyal medyada paylaşılan hadislerde yer alan ahlâkî kuralları ilahiyat Fakültesi öğrencilerinin diğer fakülte öğrencilerine oranla daha fazla dinî yaşantılarına aktardıkları anlaşılmaktadır.

Katılımcıların yüksek oranda dinî yaşantılarına aktardığı diğer bir başlık ise sosyal medyada paylaşılan hadislerde yer alan dualar olmuştur.

\begin{tabular}{lllll}
\hline \multicolumn{5}{c}{ Tablo 8. Sosyal medyada paylaşılan bir hadisten öğrendiğim duaları } \\
yapmaya özen gösteririm.
\end{tabular}

Katılımcıların \%58'i (182 kişi) bu duaları günlük yaşantısında yapmaya özen gösterdiğini, \%42'si (135 kişi) ise bu duaları yapmadığını belirtmiştir. İlahiyat Fakültesi öğrencilerinde bu oran \%57 (72 kişi) iken diğger fakülte öğrencilerinde \%59,6'dır (114 kişi). Görüldüğü üzere hem genel katılımcılarda hem de illahiyat Fakültesi öğrencilerine oranla diğer fakülte öğrencilerinde sosyal medyada paylaşılan hadislerde geçen duaları dinî yaşantıya aktarma oranı yüksektir. Burada aslında İslâm dininde birbirinden ayrı düşünülemeyecek olan zikir ve duanın katılımcılar tarafından farklı karşılandığı söylenebilir. Zira yukarıda da belirtildiği üzere katılımcıların sosyal medyada paylaşılan hadislerde yer alan zikirler ile duaları dinî yaşantılarına aktarma oranları arasında $\% 12,2$ 'lik bir fark vardır. 
Hz. Peygamber'in (sas) ahlâklı bireylerden müteșekkil düzenli bir toplum oluşturmaya yönelik çabalarından birisi de kılık-kıyafete dair olmuştur. Hz. Peygamber her zaman temiz ve düzenli olmuş ve bir Müslümanın da temiz ve düzenli olması gerektiğini birçok defa dile getirmiştir (Ebû Dâvûd, "Libâs”, 25; "Tereccül”, 1; Mâlik b. Enes, 2004, "Libâs", 1). Sosyal medyada da konuya ilişkin çok sayıda hadis paylaşıldığını görmek mümkündür. Bu nedenle katılımcılara kılık-kıyafete yönelik bu paylaşımlardaki bilgileri hangi oranda dinî yaşantılarına aktardıkları sorulmuştur.

\begin{tabular}{lcccc}
\hline \multicolumn{5}{c}{ Tablo 9. Sosyal medyada paylaşılan bir hadisten öğrendiğim kılık-kıyafet } \\
kurallarına uymaya özen gösteririm.
\end{tabular}

Katılımcıların \%57,3’ü (182 kişi) kılık-kıyafetle ilgili bu bilgileri günlük yaşantılarında uygulamaya özen gösterdiğini, \%42,7'si (145 kişi) ise göstermediğini ifade etmiştir. İlahiyat Fakültesi öğrencilerinin söz konusu bilgileri dinî yaşantılarına aktarma oranı \%63 (79 kişi); diğer fakülte öğrencilerinde ise \%53,5 (103 kişi) şeklindedir. Görüldüğü üzere sosyal medyada paylașılan hadislerde yer alan kılık-kıyafet ile ilgili bilgilerin dinî yaşantıya aktarılma oranı İlahiyat Fakültesi öğrencilerinde diğer fakülte öğrencilerine oranla daha yüksektir.

Hz. Peygamber kendisine vahyolunan Kur'ân'ın zihinlerdeki tazeliğini koruması ve insan hayatına aktarılması amacıyla hem kendisi sürekli Kur'ân okumuş hem de ümmetine Kur'ân okumayı tavsiye etmiştir. Bu durum, hem genel olarak Kur'ân'ın fazileti hem de özel olarak sûrelerin fazileti şeklinde, sahih hadislere yansıdığı gibi uydurma hadislere de konu olmuştur. ${ }^{5}$ Sosyal medyada paylaşılan hadisler arasında sûrelerin faziletine dair yapılan paylaşımlar da önemli bir yer tutmaktadır. Bu nedenle katılımcıların bu paylaşımlardan öğrendikleri bilgileri dinî yaşantılarına ne oranda aktardıkları tespit edilmeye çalışılmıştır.

Tablo 10. Sosyal medyada sûrelerin fazileti ile ilgili paylaşılan hadislerde bahsedilen sûreleri okumaya özen gösteririm.

\begin{tabular}{lllll}
\hline Kategoriler & Kadın & Erkek & Toplam & Yüzde \\
\hline Her Zaman & 7 & 4 & 11 & 3,5 \\
\hline Çoğu Zaman & 42 & 21 & 63 & 19,9 \\
\hline Bazen & 75 & 25 & 100 & 31,5 \\
\hline Nadiren & 56 & 24 & 80 & 25,2 \\
\hline Hiçbir zaman & 40 & 23 & 63 & 19,9 \\
\hline Toplam & $\mathbf{2 2 0}$ & $\mathbf{9 7}$ & $\mathbf{3 1 7}$ & $\mathbf{1 0 0}$ \\
\hline
\end{tabular}

Katılımcıların \%54,9'u (174 kişi) sosyal medyada paylaşılan hadislerde faziletinden bahsedilen sûreleri okumaya gayret ettiğini belirtirken \%45,'i (143 kişi) ise bu sûreleri okumadığını ifade etmektedir. Diğer fakülte öğrencilerinin \%56,8’lik (109 kişi) oranla ilahiyat Fakültesi öğrencilerine (\%52, 65 kişi) göre faziletinden bahsedilen sûreleri okumaya daha fazla özen gösterdiği tespit edilmiştir. 
Müslümanlar için Kadir gecesi başta olmak üzere bazı mübarek gün ve gecelerin ibadet etmek, Allah'a (cc) olan yakınlığını artırmak gibi bazı açılardan ayrı bir önemi vardır. Bu sebeple olsa gerek sosyal medyada da hakkında en fazla hadis paylaşılan konulardan birisi mübarek gün ve geceler ile bu zamanlarda yapılacak olan dualar, zikirler ve nafile ibadetlere yöneliktir. Katılımcıların bu tür paylaşımları nasıl karşıladıklarını tespit etmeye yönelik olarak da katılımcılara bir önerme yöneltilmiştir.

Tablo 11. Sosyal medyada paylaşılan bir hadisten öğrendiğim mübarek gün ve gecelerde yapılması söylenen nafile ibadetleri yapmaya özen gösteririm.

\begin{tabular}{lllll}
\hline Kategoriler & Kadın & Erkek & Toplam & Yüzde \\
\hline Her Zaman & 6 & 4 & 10 & 3,2 \\
\hline Çoğu Zaman & 54 & 19 & 73 & 23 \\
\hline Bazen & 67 & 23 & 90 & 28,4 \\
\hline Nadiren & 55 & 28 & 83 & 26,2 \\
\hline Hiçbir zaman & 38 & 23 & 61 & 19,2 \\
\hline Toplam & $\mathbf{2 2 0}$ & 97 & 317 & $\mathbf{1 0 0}$ \\
\hline
\end{tabular}

Katılımcıların \%54,6'sı (173 kişi) bu paylaşımlardan öğrendiği nafile ibadetleri yapmaya özen gösterdiğini, \%45,4'ü (144 kişi) ise yapmadığını ifade etmiştir. Illahiyat Fakültesi öğrencilerinde bu oran \%46,5'te (59 kişi) kalırken diğer fakülte öğrencilerinde \%59 (114 kişi) ile önemli bir seviyeye ulaşmıştır. Görüldüğü üzere diğger fakülte öğrencileri mübarek gün ve gecelerde sosyal medyada paylaşılan hadislerden öğrendikleri nafile ibadetleri dinî yaşantılarına daha fazla aktarmaktadır.

\section{Sonuç ve Değerlendirme}

İnternet hizmetlerinin ve iletişim araçlarının hızla geliştiği günümüzde sosyal medya araçlarının kullanımı da yaygınlaşmaktadır. Yapılan araştırmalar Türk insanının ve özellikle gençlerin sosyal medyayı sık kullandığını, gününün önemli bir vaktini sosyal medyada geçirdiğini, eğlence, iletişim kurmak gibi bazı amaçlarla birlikte sosyal medyayı bilgi edinme aracı olarak da kullandığını göstermektedir. Kullanıcılar tarafından sosyal medya aracılığıyla elde edilen bilgiler arasında dinî bilgiler de önemli bir yer tutmaktadır. Dinî bilgiler arasında hadislerin ise ayrı bir önemi vardır. Sosyal medyada her gün çok sayıda hadis yahut hadis olduğu iddia edilen metin kullanıcılar tarafından paylaşılmaktadır. Sosyal medyanın bir bilgi edinme aracı olarak kullanılabildiği düşünüldüğünde paylaşılan bu hadislerde yer alan dinî bilgilerin de kullanıcılara ulaştığı bir gerçektir.

Bu çalışmada sosyal medyada paylaşılan hadislerde yer alan dinî bilgilerin kullanıcıların dinî yaşantılarına ne kadar etki ettiği tespit edilmeye çalışılmıştır. Bu amaçla bir anket formu hazırlanmış ve Balıkesir Üniversitesi'nde eğitim gören 317 öğrenciye uygulanmıştır. Elde edilen verilere göre katılımcıların büyük çoğunluğunun (\%94; 298 kişi) sosyal medyayı sık kullandığı, küçük bir kısmının ise (\%6; 19 kişi) az kullandığı tespit edilmiştir. Sosyal medya kullanımındaki bu yüksek veriye rağmen katılımcıların sosyal medyaya güvenmedikleri görülmektedir. Nitekim katılımcıların sadece \%2,2’si (7 kişi) sosyal medyaya güvenirken \%55,5’i (176 kişi) güvenmemektedir. Bu durumun bir uzantısı olarak katılımcıların sadece \%6,6'sı (21 kişi) sosyal medyada paylaşılan hadislere güvendiğini belirtmektedir. Illahiyat Fakültesi öğrencilerinin sosyal medyada paylaşılan hadislere güvenme oranı ise \%4'tür (5 kişi). Diğer fakülte öğrencilerinde ise rakam \%8'dir (16 kişi). Dolayısıyla İlahiyat Fakültesi ile diğer fakülte öğrencilerinin arasında büyük bir fark olduğu söylenemez. Bu durum îlahiyat Fakültelerindeki hadis derslerinde sosyal medyada paylaşılan hadislere ve bu hadislerin güvenilirliğine ayrıca dikkat çekmek gerektiğini göstermektedir. Katılımcılardaki bu güvensizliğin bir sonucu olarak sosyal medyada paylaşılan hadislerin kaynaklarını araştırmaları beklense de bunun yüksek oranda gerçekleșmediği anlaşılmaktadır. Zira katılımcıların \%48,9'unun (155 kişi) sosyal medyada paylaşılan hadislerin kaynaklarını araştırdığı görülmektedir. Bu oran ilahiyat Fakültesi öğrencilerinde \%59 (74 kişi), diğer fakülte öğrencilerinde ise \%42'dir (81 kişi). Bu verinin oluşmasında da illahiyat Fakültesi öğrencilerinin almış oldukları hadis eğitiminin etkisi olduğu söylenebilir. 
Katılımcıların sosyal medyada paylașılan hadislerden öğrendikleri bilgileri dinî yașantılarına aktarma oranlarına bakıldığında özellikle nafile namaz $(\% 27,8)$ ve nafile oruç $(\% 29,9)$ içerikli hadisler ile zikir içerikli $(\% 45,8)$ hadislerin oranlarının düşük olduğu anlaşılmaktadır. Buna karşın ahlâkî kurallar $(\% 82,9)$, dua $(\% 58)$, kılık-kıyafet kuralları $(\% 57,3)$, sûrelerin fazileti $(\% 54,9)$ ve mübarek gün ve gecelerde yapılması önerilen nafile ibadetler $(\% 54,4)$ içerikli hadislerin katılımcılar tarafından dinî yaşantıya aktarılma oranının ise yüksek olduğu tespit edilmiştir. Bu sonuçlara bakarak katılımcıların sosyal medyaya ve burada paylaşılan hadislere güvenmeseler de bu hadislerde yer alan dinî bilgileri gizil (örtük) öğrenme yoluyla öğrendiğini ve dinî yașantısına aktardığını söylemek mümkündür. Zira beş maddede yer alan içeriklerin yüzde ellinin üzerinde dinî yaşantıya aktarılması bunun önemli bir göstergesidir. Ayrıca zikir içerikli hadislerin de \%45,8 oranında dinî yaşantıya aktarılmasının da dikkate alınması gerekmektedir. Elde edilen bu veriler çalışmanın üçüncü hipotezini destekler niteliktedir.

Sonuç olarak sosyal medyada paylaşılan hadislerin \%50'den fazla bir oranda katılımcıların dinî yaşantılarına aktarıldığını söylemek mümkündür. Araştırmada elde edilen veriler bu görüşü destekleyecek niteliktedir. Bu noktada sosyal medyada paylaşılan hadislerin güvenilirliği akla gelmektedir. Zira yapılan bazı araştırmalar sosyal medyada paylaşılan hadisler içerisinde sahihler olduğu gibi zayıf ve mevzu olanların da bulunduğunu ortaya koymuştur. Bununla birlikte sahih olan hadislerin nasıl anlaşılması ve yorumlanması gerektiği de ayrı bir tartışma konusudur. Bu nedenle aşağıdaki önerilerde bulunmanın gerekli olduğu düşünülmektedir:

1. Kullanıcıların sosyal medyaya ve burada paylaşılan hadislere güvenmeseler de gizil (örtük) öğrenme yoluyla bu hadislerde yer alan bilgileri dinî yaşantılarına aktardıkları göz önünde bulundurularak sosyal medyanın dinî bilgi aktarımında önemli ve etkin bir araç olduğunu kabul etmek gerekmektedir.

2. Sosyal medyada paylaşılan hadislerin tamamının kontrolü mümkün olmasa da bu hadislerin güvenilirlikleri konusunda kullanıcılara farklı mecralar aracılığıyla bilgilendirmeler yapılmalıdır.

3. İlahiyat Fakültelerindeki hadis derslerinde, farklı kitap veya kaynaklara yönelik olarak ele alındığı gibi, günümüzde sıkça kullanılan sosyal medyada paylaşılan hadislerin güvenilirliği ve kaynak bilinci konusu işlenmelidir. rilmelidir.

4. Üniversitelerin ortak seçmeli dersleri arasında medya/sosyal medya okuryazarlığı derslerine yer ve-

5. Sosyal medyada paylaşılan hadislerin güvenilirliği, kaynakları, anlaşılması ve yorumlanması ile dinî, siyasî veya başka amaçlarla istismar edilmesi gibi problem alanları hakkında akademik çalışmalara ağırlık verilmelidir.

\section{Son Notlar}

${ }^{1}$ Bu çalışma Balıkesir Üniversitesi Illahiyat Fakültesi tarafından 01.04.2021 tarihinde kabul edilen "Sosyal Medyada PaylaşıIan Hadislerin Dinî Yaşantıya Etkisi -Lise ve Üniversite Öğrencileri Üzerine Bir Araştırma (Balıkesir Örneği)-” isimli araştırmada elde edilen verilerden faydalanılarak hazırlanmıştır.

${ }^{2}$ Diğer bir çalışmada ise gençlerin sosyal medyada paylaşılan dinî bilgilere güvenmedikleri tespit edilmiştir (Demir, 2019, s. 78).

${ }^{3}$ Sosyal medyaya karşı temkinli olunması gerektiğine dair bir yorum için bk. (Arslan, 2019, s. 488).

${ }^{4}$ Gençlerin sosyal medya kullanım tercihleri için bk. (Arslan, 2019, s. 481; Subrahmanyam \& Smahel, 2011).

${ }^{5}$ Sosyal medyada farz ibadetler yerine daha çok nafile ibadetlere yönelik hadis paylaşımları yapıldığını tespit etmemiz nedeniyle katılımcılara farz ibadetler yerine nafile ibadetler sorulmuştur.

${ }^{6}$ Sûrelerin faziletine dair hadislerin değerlendirilmesi için bk. (Kanarya, 2016, ss. 81-106; Sancaklı, 2001; Avcı, 2011, ss. 546551).

\section{Kaynakça}

Altuntaş, F., ve Kul, M. (2015). Üniversite öğrencilerinin sosyal medya kullanımı alışkanlıklarının ölçümlenmesi: Van Yüzüncü Yıl Üniversitesi örneği. Akademikbakış Dergisi, (51), 414-423.

Arslan, M. L. (2019). iletişim, sosyal medya ve gençlik. 479-490. İstanbul: DiB.

Avcı, Ö., ve Sürücü, Ç. (2018). Üniversite öğrencilerinin sosyal medya etkileşimleri: Bartın Üniversitesi Örneği. Karadeniz Uluslararası Bilimsel Dergi, (40), 500-514.

Avcı, S. (2011). Hadis kaynaklarına göre Kur’an'ın faziletleri. İslam Hukuku Araştırmaları Dergisi, (17), 539-552. 
Ayaz, O. (2015). Sosyal medyanın ergenlerin dinîsosyalleşmelerine etkileriSakarya/Akyazı örneği, (Yüksek Lisans Tezi). Ankara: Yıldırım Beyazıt Üniversitesi Sosyal Bilimler Enstitüsü.

Bacanlı, H. (2002). Gelişim ve öğrenme. Ankara: Nobel.

Bacanlı, H. (2015). Eğitim psikolojisi. Ankara: Pegem Akademi.

Baş, T. (2006). Anket nasıl hazırlanır? nasıl uygulanır? nasıl değerlendirilir? Ankara: Seçkin Yayıncılık.

Bildik, E. (2019). Dini bilgi edinme sürecinde sosyal medya (Yüksek Lisans Tezi). İstanbul: Marmara Üniversitesi Sosyal Bilimler Enstitüsü.

Caz, Ç., ve Bardakçı, S. (2019). Sosyal medya bozukluğu: Üniversite öğrencileri üzerine bir araştırma. OPUS: Uluslararası Toplum Araștırmaları Dergisi, 10(17), 1100-1124. https://doi.org/10.26466/opus.521522

Çiftçi, H. (2018). Üniversite öğrencilerinde sosyal medya bağımlılı̆̆ı. MANAS Sosyal Araştırmalar Dergisi, 7(4), 417-434.

Datareportal. (2021). Türkiye sosyal medya kullanım verileri. Geliş tarihi 15 Mayıs 2021, gönderen Digital 2021: Turkey website: https://datareportal.com/reports/digital-2021-turkey

Demir, i. (2019). Dini bilgi edinme kaynağı olarak sosyal medya (illahiyat Fakültesi öğrencileriörneği). (Doktora Tezi). Çanakkale: Çanakkale On Sekiz Mart Üniversitesi Sosyal Bilimler Enstitüsü.

Dereli, M. D. (2020). Sanala veda: Sosyal medya ve dönüșen dindarlık. Ankara: Nobel Akademik Yayıncllık.

Ebû Dâvûd, S. b. el-Eş‘as. (1992). Sünen. İstanbul: Çağn.

Eldem, S., ve Elibol, T. (2020). Üniversite öğrencilerinin Instagram kullanma davranışları. Yeni Medya Elektronik Dergisi, 4(3), 157-164.

Gül, R. E. (2016). Sosyal medyada hadis kullanımı -Facebook ve Twitter özelinde-. Yüzüncü Yıl Üniversitesi Sosyal Bilimler Enstitüsü Dergisi, (30), 163-182.

İnce, M., ve Koçak, M. C. (2017). Üniversite öğrencilerinin sosyal medya kullanım alışkanlıkları: Necmettin Erbakan Üniversitesi örneği. Karabük Üniversitesi Sosyal Bilimler Enstitüsü Dergisi, 7(2), 736-749.

Kanarya, B. (2016). Fedâilu'l-Kur'an rivayetlerinin sıhhati ve bu rivayetlerin oluşturduğu Kur'an tasavvuru (Doktora Tezi). Diyarbakır: Dicle Üniversitesi Sosyal Bilimler Enstitüsü.

Karaboğa, M. T. (2018). Üniversite öğrencilerinin bir sosyalleşme alanı olarak sosyal medya hakkındaki görüşleri. Mersin Üniversitesi Eğitim Fakültesi Dergisi, 14(3), 912-936. https://doi.org/10.17860/mersinefd.475515

Karip, E. (Ed.). (2014). Eğitim bilimine giriş. Ankara: Pegem Akademi.

Kesgin, S. (2016). İlahiyat fakültelerinde hadis eğitiminin dünü, bugünü ve yarını: Tespit ve teklifler. Din Bilimleri Akademik Araştırma Dergisi, 16(1), 9-45.

Korukcu, A., Cengil, M., ve Ardahanl,, Ö. (2015). Sosyal medya ve din: Facebook örnekleminde dini içerikli paylaşımlar üzerine bir değerlendirme. 509-531. Bartın.

Mâlik b. Enes. (2004). Muvatta. Birleşik Arap Emirlikleri: Müessesetü Zâyid b. Sultan.

Özgür Güler, E., Veysikarani, D., ve Keskin, D. (2019). Üniversite öğrencilerinin sosyal medya bağımlılı̆̆ı üzerine bir araștırma. Çă̆ Üniversitesi Sosyal Bilimler Dergisi, 16(1), 1-13.

Sancaklı, S. (2001). Sûrelerin faziletiyle ilgili bazı tefsirlerde yer alan apokrif hadislerin kritiği. i̇slâmî Araştırmalar, 14(1), 129 -144.

Subrahmanyam, K., ve Smahel, D. (2011). Digital youth: The role of media in development. New York: Springer.

Wearesocial. (2021). Dünya geneli sosyal medya kullanım verileri. Geliş tarihi 15 Mayıs 2021, gönderen Digital 2021 website: https://wearesocial.com/digital-2021

Yavuz, S. (2020). Sosyal medya kullanım amaçlan üzerine bir araştırma: Illahiyat Fakültesi Öğrencileri Örneği. Bozok Üniversitesi ilahiyat Fakültesi Dergisi, 17(17), 99-132. 


\title{
MEDIAD \\ The Effect of Hadith Shared on Social Media on Religious Life: The Sample of Balikesir University Students
}

\author{
Recep Emin GÜL
}

\section{Extended Abstract}

Throughout history, people have produced information in different fields and transferred this information to the next generations in various ways. It would not be wrong to say that one of the important information transfer tools of the twenty-first century is social media. People share information about almost every area of life through this channel. Between this shared information, the density of those related to the religious field draws attention. Social media users share religious information, mostly consisting of verses, hadiths, and the words of alims. In many studies, it has been determined that religious information shared on social media is trusted by users. For this reason, the fact that social media is used as a source of obtaining religious information necessitates that the religious information included in it also be reliable.

The use of social media as a tool of obtaining religious knowledge brings to mind the latent (implicit) learning method. In this type of learning, individuals learn some information without being aware of it, for reasons such as selective perception or distraction. Learning religious information encountered in social media is also included in latent (implicit) learning.

In this study, the effect of hadiths, which have an important place in the religious information shared on social media, on the religious life of university students has been determined. The research aims to determine the degree of effect of hadiths shared on social media on people's religious lives. This study is important to determine the extent of the effect of social media, which is now an important communication tool and people can easily access all kinds of information, on people's religious lives.

The data collected through the questionnaire prepared in the research design in a quantitative design were analyzed. In the questionnaire applied to the sample group, a total of 22 items were included, including 4 demographic questions, 13 five-point Likert items (never, rarely, sometimes, often, always) containing a series of propositions about the religious life of the participants, and 5 five-point Likert items (strongly agree, agree, partially agree/undecided, disagree, strongly disagree) containing a series of propositions to measure the level of trust of the participants on social media and the information shared here.

The universe of the research consists of university students studying in Balıkesir. The sample of the study consists of a total of 317 students, 220 (69.6\%) girls, and 97 (30.4\%) boys, studying in the 3rd and 4th grades, studying at Balıkesir University, and selected by random sampling method. The 317 students that make up the sample of the study constitute $1.07 \%$ of the total population and it is thought that they can represent with a (+ -) $5 \%$ margin of error.

According to the data obtained, most of the participants ( $94 \% ; 298$ people) use social media frequently; a small number of them (6\%; 19 people) rarely use social media. It has been determined that the participants' trust in social media is extremely low. While only $2.2 \%$ (7 people) of the participants trust social media, $55.5 \%$ (176 people) do not. The level of research of the sources of hadiths shared on social media was also evaluated. Accordingly, it was determined that $51.1 \%$ (162 people) of the participants did not do source research, and 48.9\% (155 people) searched the sources of the hadiths they encountered on social media.

To evaluate the effect of the hadiths shared on social media on the religious life of the participants, some suggestions were made to the participants under eight headings. While the participants transferred the information contained in three of these propositions to their religious lives with a rate of less than $50 \%$, this rate increased above $50 \%$ in five propositions.

It is understood that the rate of transferring the hadiths containing supererogatory prayer (salaah) (27.8\%) and supererogatory fasting (29.9\%) and the dhikr hadiths (45.8\%) to their religious life is low. On the 
other hand, the hadiths (54.4\%) about moral rules (82.9\%), prayer (58\%), dress rules (57.3\%), the virtue of surahs (54.9\%), and the recommended supererogatory prayers on blessed days and nights, it has been determined that the rate of transfer to religious life by the participants is high. Looking at these results, it is possible to say that although the participants do not trust social media and the hadiths shared here, they learned the religious information contained in these hadiths through latent (implicit) learning methods and transferred them to their religious life. The fact that more than $50 \%$ of the contents in the five items are transferred to religious life is an important indicator of this. As a result, it is possible to say that more than $50 \%$ of the hadiths shared on social media are transferred to the religious life of the participants.

Considering the reliability of the hadiths shared on social media, it is considered necessary to make the following offers:

1. It is necessary to accept that social media is an important and effective tool in the transmission of religious knowledge.

2. Users should be informed about the reliability of hadiths shared on social media through different channels.

3. The reliability of the hadiths shared in the social media, which is frequently used today, and the source awareness issue should be covered in the hadith lessons in the Faculties of Theology. sities.

4. Media/social media literacy lectures should be included in the common elective lectures of univer-

5. Academic studies should be focused on problem areas such as the reliability, sources, understanding, and interpretation of hadiths shared on social media and their abuse for religious, political, or other purposes. 


\section{Çalışmanın Etik İzin Bilgileri}

Balıkesir Üniversitesi Sosyal ve Beşeri Bilimler Etki Komisyonu’nun 17/06/2021 tarihli kararı çerçevesinde çalışma etik açıdan bir sakınca içermemektedir.

Etik değerlendirmeyi yapan kurul adı: Balıkesir Üniversitesi Sosyal ve Beşeri Bilimler Etki Komisyonu Etik değerlendirme kararı belge tarihi: 23/06/2021

Etik değerlendirme belgesi sayı numarası: E-89312250-900-41938

\section{Araştırmacıların Katkı Oranı Beyanı/ Contribution of Authors}

Araştırma tek bir yazar tarafından yürütülmüştür.

The research was conducted by a single author.

$* * * * * * * *$

\section{Çıkar Çatışması Beyanı / Conflict of Interest}

Çalışma kapsamında herhangi bir kurum veya kişi ile çıkar çatışması bulunmamaktadır.

There is no conflict of interest with any institution or person within the scope of the study.

$* * * * * * * *$

\section{Intihal Politikası Beyanı / Plagiarism Policy}

Bu makale iThenticate yazııımılla taranmıştır. Intihal tespit edilmemiştir.

This article has been scanned by iThenticate. No plagiarism was detected.

$* * * * * * * *$

Bilimsel Araştırma ve Yayın Etiği Beyanı / Scientific Research and Publication Ethics Statement

Bu çalışmada "Yükseköğretim Kurumları Bilimsel Araştırma ve Yayın Etiği Yönergesi" kapsamında uyulması belirtilen kurallara uyulmuştur.

In this study, the rules stated in the "Higher Education Institutions Scientific Research and Publication Ethics Directive" were followed 